\title{
Historical cartographic materials as a source for international and cadastral boundary management in rivers
}

\author{
Haim Srebro
}

\begin{abstract}
International and cadastral boundaries are important for ensuring stable legal territorial matters.
This article deals with the long-term location and management of boundaries in rivers and the depiction of the rivers on cartographic materials. A few countries have agreed that the boundary will not follow changes in the river (like in the Mongolia-China Border Treaty), whereas most agree that the boundary will follow slow, natural and gradual changes in the river (like is stated in the Israel-Jordan Peace Treaty).
\end{abstract}

The international boundary under the British Mandate between Palestine and Trans-Jordan in the Jordan and Yarmuk rivers was defined in 1922. The cadastral boundaries were defined in these rivers in the 1930s along the international boundary.

For more than 70 years, until the Israel-Jordan 1994 Peace Treaty, the rivers have changed their channels east and westward to distances up to hundreds of meters. During that period the mandatory boundaries in these rivers changed their political status to the armistice lines, the cease-fire lines, and to international boundaries between sovereign states.

These lines were usually delineated on topographic maps in the rivers, drawn by cartographers following contemporary map revision. During that entire period the cadastral boundaries were not changed in order to adapt them to the actual position of the rivers and to the delineated international boundaries.

Owing to large water works on both rivers, including the construction of dams and diversion channels in order to meet the increasing needs of the population on both sides, the water flow of the rivers decreased dramatically to less than one tenth of the original natural flow. The population today is more than ten times than it used to be under the British Mandate. The changes in the water channels during the last 20 years since the 1994 peace treaty are in the magnitude of 10 meters versus hundreds of meters in the past. In addition, intensive land cultivation adjacent to the river banks has stabilized them.

In 2000, due to the construction of a dam on the Yarmuk River, both sides jointly fixed coordinates of the relevant boundary line in the river according to the boundary delineation in the peace treaty.

The accumulated artificial changes along both rivers have cancelled their natural behavior and have influenced the changes in the river channels. This may justify an initiative to fix the boundary lines in both rivers by coordinates according to the peace treaty delimitation, enabling the cadastral boundaries to be fixed according to the fixed international boundary line.

The article analyzes boundary line management in changing rivers in light of development of the legal approach and practice from the time of the Romans until today. It analyzes the special case of the boundary line in the Jordan and Yarmuk rivers, and introduces a proposal for stabilizing this boundary line.

The research of the changes of these rivers is based on changes in the depiction of their channels on various kinds of maps and cartographic sources, produced through the last century by many producers. They include British, German, ANZAC, Israeli and Jordanian maps and charts. The cartographic materials include large scale field survey sheets and engineering charts from the 1920s, cadastral charts from the 1930s, topographic maps produced through the last century and orthophoto maps produced since the 1990s, including joint Israeli-Jordanian orthophoto and charts produced by the Joint Boundary Commission as part of the peace agreement and its implementation. The article includes a variety of cartographic examples. 


\section{Introduction}

The purpose of boundary demarcation is to increase certainty regarding delimitation of rights on both sides of a demarcated boundary. The absence of a clear boundary line contributes to ongoing friction between those who consider themselves as the rightful owners or those who claim rights in cases of insufficient clarity. Such friction may lead to disputes, confrontation and even violence. The territorial arena, where delimitation of ownership of the rights of use is required is an important example.

The main implementations of territorial boundary delimitations are as follows: demarcation of international boundaries and demarcation of internal boundaries in a state, including administrative boundaries of government ministries and agencies, boundaries between local government entities, boundaries defining land properties and rights of use.

In order to fulfill the specific requirements of boundary making in both cases, the law requires unequivocal, fixed, and unambiguous defining of the boundary lines. In order to preserve the stability of the boundary lines, they should be precisely documented in a way that enables their maintenance and restoration (Srebro, 2014).

In the past, the tendency was to define boundaries by verbal descriptions referring to prominent landscape features, especially natural impassable barriers that are seen from far away. Such boundaries, which are regarded as natural boundaries, were based on features such as mountain ridges, rivers, shorelines, valleys, swamps, and edges of deserts. The colonial powers were inclined to delimit natural boundaries. The British Empire adopted natural boundaries during the 19th and the beginning of the 20th centuries, when dividing the British Empire into protectorates. It was easy to implement such a division, saving a lot of field work. In the course of time, the system of defining natural boundaries, by utilizing descriptions of prominent landscape features, proved to be unsuccessful in the long run, creating international disputes as a result of unclear boundary lines (Srebro, 2005). Boundary delimitations, based on river boundaries, presented other difficulties, in addition to the basic disadvantages of using natural boundaries, since a river is not a steady natural feature, it continually changes with time. A chain of mountains or a valley usually lacks a precise geographic definition that is required for boundary demarcation; however, after the two sides overcome their disputes, they agree on a consensual line and define it by coordinates or demarcate it by physical markers. A river is not a consistent geographic entity, because it depends on water sources that often change. The water volume of its flow changes, and consequently, the water's intensity and the speed of the flow also change. The water level may increase or decrease. The river may erode its banks, may carry sediment along the stream, and may change its course. Since the river changes and is unable to preserve its course, it is impossible to establish a fixed boundary line that passes through the flowing river.
This makes river boundaries leading members in the family of long-term unstable boundaries. This family also includes boundaries in changing lakes, boundaries over melting glaciers, and boundaries on unstable lands due to significant tectonic movements. Cases of unstable boundary rivers are much more frequent than the other cases of unstable natural boundaries. More than one third of the international boundaries throughout the world are river boundaries, the total length of which is about 77,000 $\mathrm{km}$ (Donaldson, 2011; IRBD, 2008). The longest of them passes along more than 2,000 $\mathrm{km}$ alongside the Rio Grande between Mexico and the

U.S.A.

The main problems arise in cases where the boundary line has to be changed owing to a change in a course of a river. In the case of international boundaries, this often initiates disputes between states, causing national discontent in the state that loses lands to another state. In land property cases it harms land property owners who lose property, sometimes cultivated lands, and registered land rights. Other problems in land boundaries arise when the river's course changes and the boundary line does not change accordingly. This causes problems in preserving the stability of the boundary line and its precise definition. In spite of arguments regarding the boundary line, other kinds of disputes may also raise. The severest one refers to the problem in which one of the sides loses accessibility to the river in the area of change. This may be reflected in losing rights of using the river's water and may be more severe in navigable rivers. Between states, such a case could result in confrontation. This was one of the reasons for the confrontation between Iraq and Iran regarding the boundary in the Shat-Al-Arab River.

States may overcome such problems by signing supplementary agreements, to ensure their rights to use the river waters in such cases. States may take drastic measures, such as forcing the stream into a steady water course such as a concrete canal. This has been implemented along part of the Rio Grande between Mexico and the U.S.A. In addition to its high cost, especially in the case of wide rivers, this solution has caused ecologic problems down-stream.

Rivers around the world are diverse regarding their size, their flow, their behavior during various seasons, the use of their water and additional parameters. The basic distinction regarding this subject refers to whether the rivers are navigable or non-navigable. Legal principles regarding land boundaries in rivers in cases of changes in the water course have been established and implemented since the time of the Romans. During the Middle Ages and later on, the Roman principles regarding this issue were adopted. In the 18th century, the scholar Grotius expanded these principles, and applied them to land property boundaries between individuals and to boundaries between states.

These principles distinguish between two types of changes in the water course of a river: one is a natural, slow and gradual change during the accretion/alluvion process. It cannot be perceived when it occurs, when the 
water of a river carries away soil from one bank of the river to its other side (usually under different ownership). In the case of an international river boundary, the river often carries away soil, transferring a piece of land from one state to another. According to the accretion principle, in such cases the boundary line follows the changes in the course of the river, and the course of the boundary line is consequently changed to the new location of the river course.

The other case refers to a sudden and steady change in the water's course, in the case of a river (avulsion), which can be perceived when it occurs, either as a result of natural reasons or as a result of man-made activities. According to the principle of avulsion, such a change does not justify a change in the boundary line. This case should be considered as if a new river has been formed elsewhere. The boundary line remains in the former abandoned water course even if it is dry. In this case there is a break off between the course of the river and the course of the boundary, and one of the states loses its access to the river at this location.

In order to avoid situations of unstable boundaries that are predicted to cause future disputes, some countries have tried to fix the river boundary between them, with reference to the position of the course of the river on a jointly agreed date. In order to overcome the dynamic nature of the river, they have tried to physically force the river's flow into a rigid concrete canal. Usually this did not solve the problem because new problems arose. In other cases, countries agreed to fix the boundary line in coordinates. This option is much easier to implement today than in the past, since the use of satellite surveying, like GPS, is much more common. Even the International Court of Justice has adopted this method in its decision concerning the dispute between Benin and Nijer regarding the boundary line in River Niger, defining the boundary line in a list of coordinates (ICJ, 2005). The Israel-Jordan Joint Team of Experts (JTE) similarly fixed the boundary line in the River Yarmouk, following the construction of a dam on the river (Srebro, 2012).

The absence of one comprehensive method that can prevent river boundary problems and disputes is why, in spite of the development of law regarding this subject, including common law, in spite of decisions in courts and arbitrations, and in spite of many bilateral agreements between states that could support customary law, an obligatory international convention regarding defining and maintaining river boundaries has not been developed. This is unlike the UN Convention on the Law of the Sea 1982 (UNCLOS).

This argument was even used by the British administration in Palestine and Trans-Jordan to justify their decision in 1927 regarding the boundary in the Jordan River, following a flood that altered the water course of the river, consequently transferring a strip of land from Palestine to Trans-Jordan (Toye, 1989 pp 795805).

This article deals with the international boundary between Israel and Jordan in the Jordan and Yarmouk Rivers, and with the land settlement boundaries of Eretz Yisrael (Palestine) and of the State of Israel along these rivers in light of legal principles, court decisions, agreements, and customs regarding delimitation of international river boundaries and regarding the attitude to the delimitation in cases of changes in the river's course. The water's courses of both rivers have changed since the original definition of the boundary between Palestine and TransJordan under the British mandate in 1922, owing to natural and man-made changes.

Part of these changes resulted in fixing the boundary line in coordinates.

\section{River boundaries}

Disputes over lands have been known since ancient times, as well as the requirement to settle land boundaries and manage and register land transactions, early before the development of international boundaries. Since an objective means of defining boundaries by coordinates did not exist in ancient times, boundaries used to be defined by describing them in reference to natural landscape features, augmenting the descriptions by using physical man-made markers.

Because of their nature, artificial markers were known to disappear over time, especially if there were interested people nearby. Therefore, some cultures sanctified such boundary markers and even ordered punishment and divine curses for offenders who damaged them (Solel, 1991). The use of landscape features in boundary descriptions used to be the first choice. This included roads, trees, rivers, constructions, and stone fences. Rivers were easy to recognize in the field and were natural obstructions and barriers. They were used as borders at the local, tribal, administrative, and international levels.

At the local level, land was cultivated until the bank of the river. The edge of the cultivated land moved according to the high and low tides and according to the changes in the river's course. Village lands used to be limited by rivers, especially in cases of wide rivers, which were difficult to cross. At the tribal and national levels, the river was used as a defense line against aggressors, and therefore, it was used as a boundary. With the development of civilization and the construction of bridges over rivers in fertilized and populated valleys, rivers also acted as a bridge between populations living on both sides of the river. Owing to their easy visibility, being easily used as natural borders, rivers eliminated the need for field marking and surveying, and were still used for boundary delimitation in the 20th century.

In order to define a boundary in a river the two countries should make decisions regarding a few questions: Where should the boundary be delimited - in the river (in its center or elsewhere) or along its banks? How should the boundary maintenance be managed over time, considering that the river is a living dynamic entity that changes according to the flow of water from its sources? How should the rights of use be allocated and how should they be divided between the states on the two sides and 
along the river? The allocation of the rights to use the river's water is important because of the global developing water crisis as a result of the climate change and the warming of the Earth. This phenomenon dries water sources and significantly reduces the water volume and the flow of rivers. It is also important due to the rapid increase in the world's population and especially for populations living along rivers and using their water (Graiger and Conway, 2014). Exploitation of river waters influences boundaries in rivers, but this subject is not discussed here in depth.

Usually it is common that a boundary river between two countries is equally shared between them, and that the boundary is delimited in the center of the river. The case of the river boundaries between Germany and the Netherlands is an exception, however, because according to the agreement between the two countries, in cases where the international boundary between the countries follows a river, the closer bank belongs to the relevant country and the river is common to both countries. In certain cases, where a strong power or a strong country ruled one of the banks of the river, it was determined that the boundary line follows the bank of the weaker country and that the water is under the sovereignty of the stronger one.

There are a few methods of delimiting a boundary line in the center of a river. The main distinction is between navigable and non-navigable rivers. In the case of nonnavigable rivers it is common to delimit the boundary in the geographic center of the river ${ }^{1}$. This is valid in land settlement boundaries inside a country where land properties are located on two sides and the boundary passes in the center of the river. It is also valid in the case of a boundary line along the median line between two countries. There are a few methods of delimiting such a center line. One common method is the equidistance one, in which the center line is defined by connecting points along the center of the river, which are at the same distances from prominent points on the two sides (along the two banks) of the river (Boggs, 1940; Srebro, 2005). Where a river splits up into two water courses it is common to choose the main one (Boggs, 1940; Jones, 1945).

In navigable rivers, consideration is usually given to the access of each of the countries to the navigation course and preference is usually given to defining the boundary line along the main navigation course. The navigation

\footnotetext{
1 "Where properties are separated

by a natural non-tidal river or a

stream, the presumption is that the boundary follows the center line of the water (ad medium filum aquae) so that each owner has half of the bed." (UK Land Registry Guidance - Land Registry plans: boundaries (practice guide 40 supplement 3, updated 25 June 2015)).
}

course is usually defined along the course of deepest places (also called thalweg, though the meaning of the term is not unequivocal). The ICJ referred to this in the decision regarding the Botswana-Namibia dispute (ICJ, 1999), determining a leading rule, though not a decisive one, regarding the preference of the thalweg in navigable rivers. The ICJ repeated this in the decision regarding the Benin-Nijer dispute (ICJ, 2005) ${ }^{2}$. The Court adapted the boundary line to the existing islands along the river's water flow.

\section{Boundary Maintenance in a River}

Maintenance of boundaries in rivers is basically required because of the changing nature of river courses. This is one of the cases of changing boundaries caused by physical long-term changes in nature. Other cases are changes of boundaries due to changes in lakes, due to melting glaciers, or as a result of tectonic movement of the earth.

Rivers, by their nature, continually change with time. An increase in the water volume causes the tide to elevate and the extent of the river banks is governed by the side slopes of their banks. Sometimes the strong flow creates floods, sweeping the soil from the bed or the banks of the river. After heavy rains or melting snow, the flow of a river increases, and large amounts of eroded soils are carried away by the flow and sink as sediment along the stream. Sometimes the river overcomes obstacles in the course of the stream and cuts through a new water course, shortening the existing course, or meanders aside where the valley is wide, the slope is moderate, or the soil is soft. On the other hand, when the flow slows down and the weak stream does not have enough power to overcome the obstacles of silt that accumulate along the stream, and if the soil is soft and the land is flat, the river bypasses the obstacle. The width of the river and its water course changes if it passes through a wide flat valley and not through a narrow, deep rocky gorge.

The dilemma of maintaining a boundary line in a changing river concerns whether to keep the original boundary line in spite of the changes in the river or to move the boundary line to the new water course. In the

\footnotetext{
2 "144. The Chamber would recall that, in the case concerning Kasikili/Sedudu Island

(Botswana/Namibia), the Court observed that: "Treaties or conventions which define boundaries in watercourses nowadays usually refer to the thalweg as the boundary when the watercourse is navigable and to the median line between the two banks when it is not, although it cannot be said that practice has been fully consistent."" (I.C.J. Reports 1999 (II), p. 1062, para. 24).
} 
past, the main legal and scholar discussions regarding this issue referred to river changes because of the transfer of soils from one bank of the river to the opposite one. In fact, often the river carries eroded soils from upstream out of the area of change, or from one of the banks, and the sediments sink downstream, sometimes on the bank of the same state from which the soil has been taken.

From the legal point of view, the distinction is between slow, gradual, and natural changes in the water course and between sudden sharp changes, whether natural or man-made. Such an example regarding land property law, reflecting common law, can be seen in the British Land Registration Law (LRA, 2002). According to this law, a boundary line that follows a river or a stream between two registered land parcels is located in the center of the water course and changes according to the change in the river, if the change is natural and gradual over time (UK Land Registry, 2015) ${ }^{3}$. Changes of that type - alluvion, accretion, diluvion or erosion - are recognized in land property law within the common law as changing borders of parcels, in spite of the fact that the boundaries are delimited in registered plans. The British Land Registry law even specifies that if the owners on both sides of the river want to deviate from this rule and agree on it, they must register that agreement in order to receive recognition by the Registry.

On the other hand, if the change in the water course is a result of man-made activity, the changes in the course are not recognized by common law as leading to a change in the boundary line. In the case of a sudden and steady change in the water course, whether natural or as a result of man-made activity, the boundary line remains in its former place, before the change in the water course (UK Land Registry, 2015) ${ }^{4}$. In case of wide rivers that are

\footnotetext{
3 "The doctrine of accretion and

diluvion recognises the fact that where

land is bounded by water, the forces

of nature are likely to cause changes in

the boundary between the land and the

water. We would expect these changes

to be gradual and imperceptible. As

the watercourse changes naturally and

progressively with time, so the land

boundary follows it. There may be

some gain, there may be some

loss. The law accepts this and considers it to be fair."

4 "If a violent flood wrenches the

watercourse suddenly but

permanently into a different

direction so that a substantial and

recognisable change in the

boundary has taken place, then

the doctrine of accretion does not

apply. Neither does it apply if the

changes are man-made." And

elsewhere: "Where there is a

sudden, but permanent change in
}

subject to high and low tides, the land settlement boundary bordering the water is located at the front line of the mean high and low tides. It is common that the water space beyond that line belongs to the state.

The legal grounds of the accretion/alluvion doctrine evolved in the Roman laws, which had determined that a slow gradual change in the water course causes the boundary line to follow the river to its new course ${ }^{5}$, but that a sudden and continuous change does not change the boundary line. In time, this legal custom took root and found expression in the theory of law and in the studies of law during the Middle-Ages and in modern times. In the 13th century the British jurist Bracton clarified that the legal principle of adding land as a result of river accretion is valid when the process is slow and unperceivable, but if the process of change is perceivable, then the land transfer is not legally valid (Bracton, 1883 according to Donaldson, 2011). Bractons attitude had a significant influence on the development of common law. In the 18th century the Dutch scholar Grotius expanded the legal principle of changing the boundary line as a result of accretion, from the land property domestic law to international boundaries in rivers. In his work: Of the Rights of Wars and Peace he determined that rivers are natural boundaries that used to serve as natural barriers, defending from enemies, and they define legal limits between states. His view was that the Roman law regarding the boundaries of private property in the case of alluvion should also be valid in the case of boundaries between kingdoms. A river that defines a boundary defines it in a specific course, and if the course is changed slowly and gradually in a natural process, while transferring soil from one side of the river to the other side, it changes the boundary of the territory. However, if a river changes its course suddenly from one place to another, this is not considered any more as the old river in

the course of the stream, whether or not it is due to natural

causes, the boundary will remain along the center line of the former bed."

${ }^{5}$ The Roman law says: "what the river adds to your field by alluvion, becomes yours by the law of nations" (Donaldson, 2011). The Justinian Institutes, that catalogued the Roman legal tenets remarked: "20. The law of all peoples makes yours any alluvial accretion which a river adds to your land. An alluvial accretion is one which grows on so gradually that you cannot tell at any one moment what is being added. 21. If the river's current rips away a piece of your land and carries it down to your neighbor, it clearly remains yours (Birks and McLeod, 1987 cited by Donaldson, 2011). 
a new course, but as a new river, and it does not change the boundary of the territory (Grotius, 1715).

The views of Grotius were adopted and later on developed by Vattel (1787), who held the view that the alluvion principle that had been developed regarding private land property rights is also relevant for defining international boundaries in rivers. He expressed this view in 1758 in his publication: The Law of Nations (Droit de Gens).

There is analogy between the doctrine applied to land boundaries and the doctrine applied to international boundaries. The similarity is greater in cases of nonnavigable rivers and streams. In these cases, delimitation of the boundary line in the center of the water course is considered most justified regarding the two states. Nevertheless, delimitation of international boundaries is more common in wide navigable rivers, flowing between countries, since such rivers had usually separated between tribes and peoples and had served as barriers, defending them from invasion.

The historic use of rivers for boundary delimitation has taken root and it left its mark on many river boundaries existing today. Some of them are domestic, separating districts, sometimes autonomic ones. Such examples are river boundaries between states in the US, like the Missouri River between Nebraska and Iowa; along the Mississippi River between Missouri and Illinois, Kentucky and Tennessee (and between additional states along its course). Other examples are the boundaries along the Huang He River in China between Shaanxi province and the Henan and Shanxi provinces. Parts of these river boundaries follow rivers that pass between countries, like along the Rhine River between Germany, France, and Switzerland.

Some examples are the boundaries along the Danuba/Donau/Donev/Donaria/Doni/Dona between Bulgaria and Romania, and between many other countries along its course, and for example, the boundaries along the rivers Argun and Amur/Heilong Jiang between Russia and China, and along the Shatt-al Arab between Iraq and Iran.

Wide international rivers are usually used for sailing. Therefore, navigation is an important parameter that is considered when choosing the center or the main course of navigation for delimiting the boundary line. There is no obligatory international convention regarding river boundaries, similar to the convention regarding delimitation of maritime boundaries (UNCLOS 1982). Therefore, one usually relies on the decisions of ICJ and of international arbitration tribunals, on customary practice in agreements between countries, and on the written opinions of scholars.

In the middle of the 19th century, the reference to the accretion/alluvion doctrine became standard in legal materials discussing river boundaries in international law (Donaldson, 2011).

The decisions and customary practices regarding the issue in the 20th and the beginning of the 21 st centuries reflect significant reliance on the decisions of the US Supreme
Court from 1892 and later in disputes between states in the USA regarding river boundaries between them (in addition to previous cases in 1875 and 1890 that were not between states). The relevant decisions referred to the influence of natural and gradual or sudden changes in rivers on the boundary lines. In 1892 the US Supreme Court decided that the boundary between Nebraska and Iowa in the Missouri River would not follow a change in the course of the river, because it had been a sudden change (US Supreme Court, 1892, Iowa vs Nebraska). Similar decisions of this court regarding river boundaries in the US followed this decision.

The most famous arbitration decision regarding this subject, which is used even today as precedence for a decision of an international court or tribunal regarding the legal acceptance of the accretion and avulsion principles in international law, was given in 1911 regarding the USMexico dispute (the Chamizal Case). The arbitrators decided that the piece of land that had been transferred from the Mexican side to the American side, as a result of changes in Rio Grande water course, belongs to Mexico. The arbitrators accepted the Mexican argument regarding sudden changes in the water course and rejected the American claim that the changes were gradual. However, the US did not comply with the decision. In 1963 the disputed area was divided according to an agreement between the two countries. Following this arbitration decision, the principle of accretion/alluvion was established regarding accepting the principle that the boundary line follows changes in the water's course of a river, if these changes are slow and gradual, but when the change in the water's course is sudden, in an avulsion process, there is no change in the boundary line and it remains in its former course (Shaw, 2014). The arbitrators in this case determined, for the first time in an international decision, that the principles of accretion and avulsion are known principles in international law ${ }^{6}$.

\footnotetext{
${ }^{6}$ The arbitrators in the Chamizal case gave significant weight to relevant decisions of the US Supreme

Court regarding accretion and avulsion. They also referred to the early comments in this regard of the US Secretary of the Interior in 1856 Cushing, who was considered an authority on international law, at the time of drafting the US-Mexico boundary treaty (Donaldson, 2011). The arbitrators quoted Cushing's comment: "If the river deserted its original bed and forced for itself a new channel in another direction, then the nation through whose territory the river thus broke its way did not lose the land so separated; the international boundary in that case remaining in the middle of the deserted river bed" ( IBC, 1911).
} 
The Shatt-al-Arab case between Iraq and Iran was another early known dispute. The 1937 agreement regarding the boundary line in the river determined that the boundary line will follow the deepest course of the river. Various methods regarding delimitation of the boundary line have been adopted in different sections along the river.

Many scholars have described methods to delineate a median line, every point of which is equi-distant from prominent points on the opposite banks (Boggs, 1940; Jones, 1945; Bouchez, 1963; Srebro, 2005). A 1934 decision by the US Supreme Court delimited a boundary line in the thalweg of a river. According to the Iran-Iraq agreement the deepest water course is decisive. Lauterpacht (1960) discussed the choice between the deepest course and the deepest navigation course. The definition of thalweg is more complicated when an island splits up the stream into a few channels. In such cases the main possibilities are: to choose the main water course or to draw a line through the island. The 1924 NorwayFinland agreement shows an early example of such a case. Bouchez (1963) and Biger (1988) emphasized that a navigation channel has width and it is not a line. However, agreements define boundary lines and the width is taken care of by supplementary agreements.

Unilateral artificial changes in a river are forbidden. In any case of a change in the course of a river as a result of man-made activity, the boundary line does not change. It will remain in its former course, even if the result of it is that the boundary will pass out of the river. In any case, two countries that come to an agreement regarding their boundary line in an international river (when no other country is involved) are sovereign to agree as they desire regarding its place, on the method of delimitation, and on the way of maintaining the boundary line in case of changes in the river. Examples of different approaches are reflected in the following: the 1963 China-Mongolia agreement (Department of Commerce, 1971) says that in case of a change in the river bed the boundary remains in its place unless otherwise agreed ${ }^{7}$, whereas the 1994 Israel-Jordan peace treaty says that in case of natural changes in the course of the river (accretion or erosion) the boundary line will follow the changes unless otherwise agreed.

\footnotetext{
7 "If, for natural reasons, the bed

of the main course of the boundary river should change, the 7

original boundary line shall be retained, unless the two parties decide otherwise."
}

\section{The Boundary in the Jordan and Yarmouk Rivers}

\subsection{Geographical background}

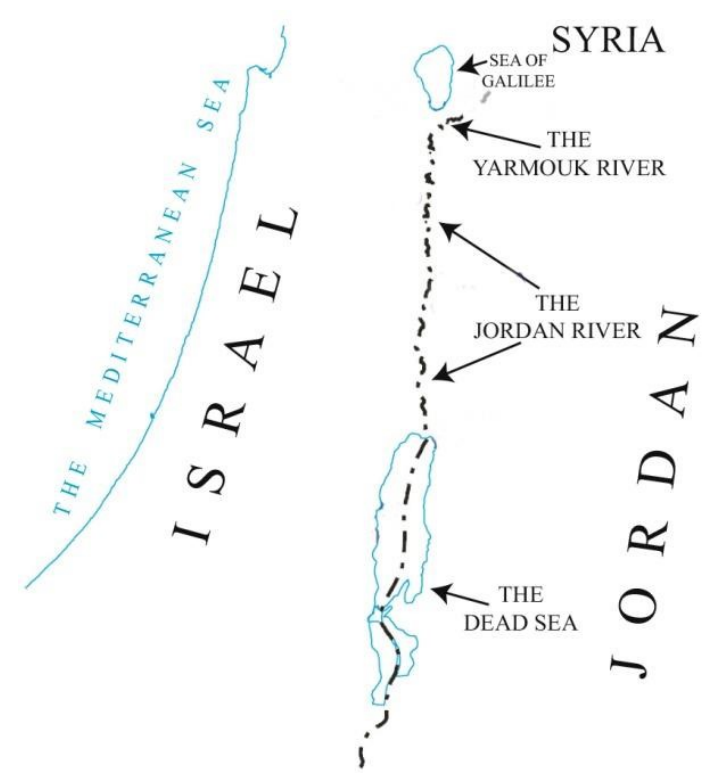

Figure 1: The Israel-Jordan boundary in the Jordan and Yarmouk rivers

The Jordan River is the longest river in Israel. It flows from north to south along the Jordan Valley, which is part of the Dead Sea Fault (the Syrian African fault), along $250 \mathrm{~km}$, from its sources in the vicinity of Mt. Hermon until reaching its estuary, into the Dead Sea, the lowest place on earth. Its drainage area is about 18,300 square $\mathrm{km}$. The Jordan River consists of two parts. The northern part - the upper Jordan (also called the mountainous Jordan) flows between the Golan Heights on the east and the Galilee Mountains on the west, in a fast stream original boundary line shall be retained, unless the two parties decide otherwise."

along a steep slope into the Sea of Galilee. Its average annual water volume is about $500 \mathrm{MCM}$. The southern part - the Lower Jordan - exits the Sea of Galilee and flows southwards through the Jordan Valley until the Dead Sea. To the east of it are the Gilad and Moab mountains, the heights of which rise up to $1237 \mathrm{~m}$. In the north-west it fringes the Lower Galilee and the Bet Shean Valley, which are relatively low. The Shomron and Judean mountains, which follow it on the west side, are lower than the mountains on the east side, though they rise up to $1000 \mathrm{~m}$ in the south. The Israel-Jordan international boundary runs through the Lower Jordan along $105 \mathrm{~km}$ of direct distance and about $200 \mathrm{~km}$ along the meanders of the water's course in a slope of $0.8 \%$. The current ratio between the distances is about 1:1.86, more than the average of $1: 1.5$ of twisted rivers throughout the world. The common width of the river is 27-30 $\mathrm{m}$ and its depth is 1-3 $\mathrm{m}$. In some areas it may be crossed by foot. The river bed passes through a flooding path along the lower level of the Jordan Valley, which is called Geon-Ha'Yarden (The Zor), $1200 \mathrm{~m}$ wide, but in 
few places only a few hundred meters wide. The river cuts its bed in soft alluvial soil that has accumulated on top of thin grain sediments of Lissan formation, composed of lime stone, gypsum and minerals that had sunk during the time of ancient Lissan Lake. The lowest level of the Jordan Valley, through which the river flows, is limited on both sides by slopes, 5-25 $\mathrm{m}$ high (up to 40 $\mathrm{m}$ in the south), above which on both sides exists the mid-level of the Jordan Valley called Kikar Ha'Yarden the Ghor. The lands on this level are largely cultivated on the north- western Israeli side and all along the Jordanian east side (as a result of the Ghor Canal -the Abdalla Canal - and additional water projects). On both sides, above the mid-level of the valley, is located the upper level of the valley.

The Jordan Valley area, through which the Jordan River flows, is considered to be on the edge of a dry desert, located on the "shadow of rain". The climate is hot and dry. The average temperature is $24^{\circ} \mathrm{C}\left(30^{\circ} \mathrm{C}\right.$ during summer and $15^{\circ} \mathrm{C}$ during winter). The precipitation is low $(400 \mathrm{~mm}$ north of the area, $250 \mathrm{~mm}$ near Tirat Tsvi, $150 \mathrm{~mm}$ in the area of Jericho). Being on the "shadow of rain" on the west side, the surface flow usually appears in short ranges of floods coming from the east as a result of rains in the mountains. The main wadis from the east are Wadi Zarqa and Wadi al-Yabis, in addition to the Yarmouk River, which used to be the main water source of the lower Jordan, until it ceased to supply water to the Jordan River due to the construction of dams on the river, to the Ghor diverting canal and to other water projects.

The natural annual water volume of the lower Jordan before the construction of the water projects used to be 1200-1500 MCM. According to Brawer (1968), the peak of the flow of the Jordan River into the Dead Sea was $1650 \mathrm{MCM}$, in the years 1942-3. Since the construction of the Deganya dam in 1932, there has been a significant decrease in the flow of the Jordan River. Most of this was due to a series of dams constructed on the Yarmouk River by Syria and Jordan in the 1960s, to the construction of the Ghor canal, which diverts the Yarmouk water to the Jordanian side of the Jordan Valley, to the construction of the Israeli National Water Carrier (the last two were launched in 1964), and due to the closing of the Deganya dam, preventing the water from exiting the Sea of Galilee to the lower Jordan River.

The main sources of the base flow of water to the lower Jordan today are the salt water carrier along the Sea of Galilee, the sewage water from the Israeli fish pools and cultivated lands, and the excess of irrigation water and sewage water from the Jordanian cultivated lands.

The base flow is about 20MCM a year (Holtzman, 2002), which is the only source during dry years, increasing up to $120-150 \mathrm{MCM}$ draining to the Dead Sea during rainy years, including the additional surface flow, added mainly by lateral wadis. This is about one tenth of the flow in the past. The weak water flow contributed to the development of the dense bank plantation that stabilizes the river banks, reducing the river meandering process.
Farmers on both sides of the river cultivate the lands beyond the river banks along the Zor.

Being part of the Dead Sea Fault, the Jordan Valley is influenced by tectonic activities. High magnitude earthquakes occur as a mean, once every hundred years. Over 500 people died and 700 were wounded on both sides of the valley during the 1927 earthquake. The mean annual relative shift between the two sides is about $1 \mathrm{~cm}$ of the east side northward.

A few processes have influenced the course of the lower Jordan during the last decades. Before the construction of the water projects that dried the river, the channel of the river had been naturally pushed westward inside the Zor by alluvial sediments carried away by lateral seasonal floods of the wadis draining the rain waters and the surface flow from the high mountains on the east side. As a result, the river bed is closer to the western edge of the Zor. A research study shows that since 1945 the lower Jordan meanders have been shortened and the ratio between its straight length and its actual (twisting) length decreased from $1: 2.4$ to 1 :

1.86. The reasons for that phenomenon are as follows: (a) A decrease in the water flow and the prevention of alluvial sediments that used to be carried away by the Yarmouk River, sinking along the course of the lower Jordan. In addition, the silt that used to be carried away by the wadis draining from the east was also blocked by local dams. The absence of silt has increased the velocity of the river's flow, increasing its erosion power. (b) Artificial stabilization of the river banks in order to prevent flooding of the cultivated lands, sweeping away cultivated soils and disturbing the natural trend of the river to meander. (c) The water level of the Dead Sea is decreasing rapidly due to reduced water sources and to rapid evaporation. This increases the slope of the lower Jordan, increasing its velocity and increasing its trend to shorten the river channel by shortening or deserting existing meanders.

The Yarmouk River is the main tributary of the Lower Jordan. It is a perennial stream, $17 \mathrm{~km}$ of its length follow the Israel-Jordan boundary, and an additional $17 \mathrm{~km}$, which were not specified in the Israel-Jordan peace treaty, follow the boundary between the Golan Heights and Jordan. Its drainage area is 7250 square $\mathrm{km}$ (Kalvo and Ben Tsvi, 2005) in the Golan Mountains as well as in the Bashan and in the Gilad. The Yarmouk begins at the valley of Damascus and flows to the south of Syria, between the Horan and the Bashan in the north and the Gilad in the south, westwards until its confluence with the Jordan River in Naharayim, about $10 \mathrm{~km}$ south of the Kinneret (Sea of Galilee). The Jordan-Syria and JordanIsrael boundaries follow the Yarmouk along its western lower part. The river bed along its lower part passes through a deep canyon with basalt walls until its exit from the mountainous area to the open area of the Jordan Valley near Naharayim. Its annual water volume flow is $460 \mathrm{MCM}$, flowing mainly during winter floods. It passes through soft lime stone and it used to carry large amounts of alluvial silt to the lower Jordan. This silt used to sink 
along the course of the river and its estuary to the Dead Sea.

During the years 1927-1932 the Naharayim Dam was constructed near its confluence with the lower Jordan as part of a hydro-electric power station, and a basin was dug for a reservoir as part of the project. Since the 1960s Syria and Jordan have constructed dams on the river for supplying drinking water and for irrigating agricultural lands in Jordan. In 2000 a dam was constructed jointly by Jordan and Israel on the river, near Adassiya-Ashdot Yaakov to support Jordanian water requirements, as part of the implementation of the 1994 peace treaty. The main water project on the Yarmouk is the Ghor canal (the Abdalla Canal), which has been built in stages since the 1960s. This canal diverts the Yarmouk waters southward along the mid-level of the Jordan Valley, east of the river, until reaching an area near the Dead Sea. The canal is the main water source of the Jordanian agriculture in the Jordan Valley. These water projects have dried up the main water source of the lower Jordan.

The Yarmouk Valley has been used by military forces throughout history as a pass from the East towards Palestine. A few famous battles took place in this area, such as the Yarmouk Battle between the Muslims and the Byzantines in $636 \mathrm{AD}$, and the journey of Sallah A-Din to Palestine. In 1905, the Ottoman authorities built a railway along the valley to connect the Hejaz railway to Haifa and Palestine.

Both rivers are narrow rivers of the type that is considered non-navigable.

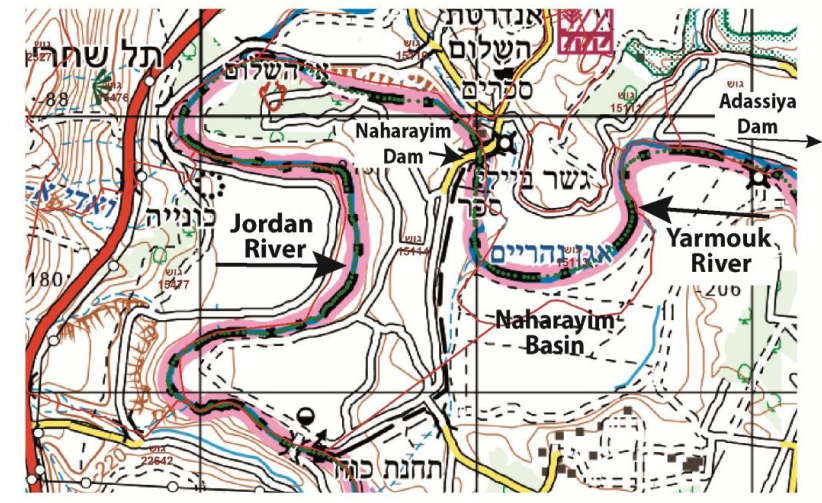

Figure 2: The Jordan-Yarmouk intersection area today (on a GIS based map)

\section{Historical background regarding the boundary line}

During the 1920 Paris conference Great Britain and France agreed that part of the boundary between the French Mandate over Syria (and Lebanon) and the British Mandate over Palestine (and Trans-Jordan) and Mesopotamia, would pass along the Yarmouk River.

The mandatory eastern boundary of Erets-Israel (Palestine) in the Jordan and the Yarmouk rivers was defined by the British High Commissioner and published on September 1, 1922 in an Order in Council (OIC) as part of the line separating Palestine and Trans-Jordan. The purpose of this definition was to include it in article
25 of the British Mandate over Palestine, in order to define a line to the east of which the special rights to build a homeland for Jews in Palestine will not be valid. The definition of this boundary line was approved by the League of Nations on September 23, 1922 as part of the documents of the Mandate. The description of the line in the Order was published in the Official Gazzete on September 1, 1922, and a similar definition was included in the agreement between the governments of Great Britain and Trans-Jordan in 1928. Since the beginning of the mandatory period until the independence of Jordan in May 1946 Great Britain governed both sides of the two rivers. Between May 1946 and May 1948 Great Britain governed only Palestine on the west side of both rivers. During both periods the separating line had the status of an international mandatory boundary.

On April 3, 1949, after the War of Independence, Israel and Jordan signed an Armistice Agreement, defining an Armistice Demarcation Line (ADL), which was valid until the Six Day War in June 1967. A cease-fire line between the two states existed along the rivers between 1967 and the October 26, 1994 peace treaty. The peace treaty defined an international boundary line between the states.

\section{The course of the boundary line in the Yarmouk and Jordan rivers}

According to the 1922 OIC this line follows the center of the rivers:"a line drawn... up the centre of ... the River Jordan to the junction of the latter with the River Yarmuk, thence up the centre of the River Yarmuk ...". No maps were attached to the boundary definition.

The 1940s 1:20,000 British Mandatory maps showed the actual courses of the two rivers, and in many cases, mainly in the Jordan River, they also showed former abandoned courses of the river, usually showing the boundary line along the new course of the river.

The ADL had been originally delimited on a 1:250,000 map that was signed by both sides and attached to the General Armistice Agreement (GAA). However, a map of that scale is not adequate for delimiting a boundary line. In addition to the poor quality of the map, the width of the delimited line, which covers 400 meters, does not properly represent the course of rivers the actual width of which is tens of meters. Shortly after the GAA, the line was transferred to a mosaic of 1:100,000 maps. This was an improvement but these maps were also not suitable for the required purpose. In addition, the delimitation differences between the locations of the ADL on both maps exceeded one kilometer in certain locations. The ADL only partly followed the international mandatory boundary. The West Bank had been annexed to the Kingdom of Jordan. Along the section of the Jordan River, from its confluence with Khor Buleibil southwards until the Dead Sea, the Jordan River became a domestic Jordanian river. The ADL along the Jordan and Yarmouk rivers from Khor Buleibil northwards followed the verbal description of the international mandatory line except the section of the course in the 
Naharayim basin, where a straight diagonal armistice line replaced the course of the rivers.

In spite of the fact that the GAA did not specify any instructions regarding the adaptation of the ADL in the rivers to the changes in the course of the rivers, the line was changed in order to adapt it to the changes in the rivers, except for the Naharayim basin where the ADL did not fit the river course. The 1:20,000 Israeli maps of the 1960s showed the actual courses of the two rivers, discarding former courses of the Jordan River, showing the boundary line in the actual course of the river at the time of the mapping. This shows that the cartographers of the maps published during the mandatory and armistice periods adapted the presentation of the boundary line in the river to the changes in the course of the river. Early maps of the Survey of Israel show that the international mandatory boundary in the Yarmouk River was shown on these maps in its original location in the $1920 \mathrm{~s}$, before the Naharayim basin was excavated for the Hydro-Electric Power Station.

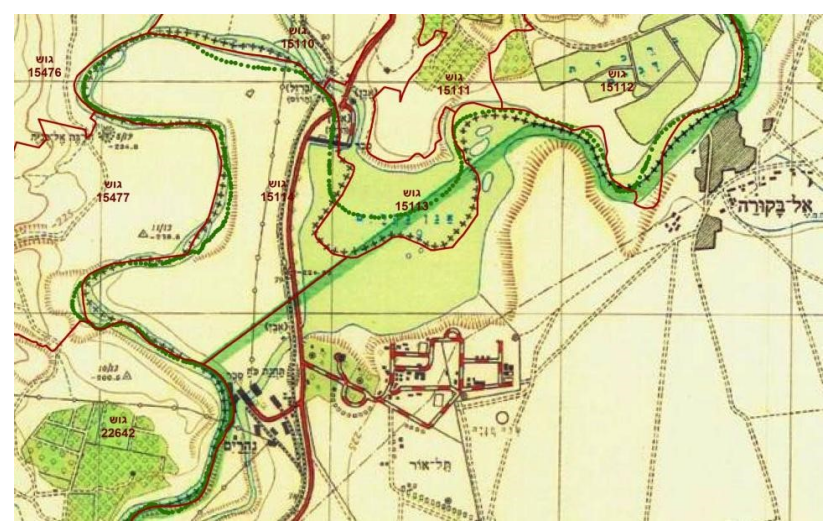

Figure 3: The ADL in Naharayim shown on an Israeli 1953 topographic map (the diagonal line).

Additional lines shown are: the international mandatory line $(+++)$, the land settlement line showing the location of the rivers in the 1930s (in red), and the 1994 line (in green dots)

After June 1967, the southern section of the Jordan River returned to be the separating line between Jordan and Israel, changing the status to become a cease-fire line. In addition to the section between the Dead Sea and HamatGader (Al-Hama), a new section, a line of about $17 \mathrm{~km}$ long, had been added along the Yarmouk, separating the Golan Heights and Jordan. Until the 1994 Israel-Jordan Peace Treaty the cartographers continued the trend by adapting the cease-fire line to the actual course of the rivers.

The Israel-Jordan boundary was defined in the 1994 peace treaty as follows: "Article 3 - International Boundary: 1. The international boundary between Israel and Jordan is delimited with reference to the boundary definition under the Mandate as is shown in Aneex I (a), on the mapping materials attached hereto and coordinates specified herein. ... 5. It is agreed that where the boundary follows a river, in the event of natural changes in the flow of the course of the river as described in Annex I (a), the boundary shall follow the new course of the flow. In the event of any other changes the boundary will not be affected unless otherwise agreed."

The boundary line in the Yarmouk and Jordan rivers had been delineated in Annex I (a) to the agreement in the center of the courses of the two rivers, as interpreted by the Joint Team of Experts (JTE) on 1:10,000 orthophoto sheets made from 1993 photographs. In order to decide about the delimitation of the boundary line in cases where small islands existed along the course of the river, the chairs of the JTE jointly decided during a helicopter flight whether the boundary line follows one of the channels chosen as the main channel or whether the line bisects the island.

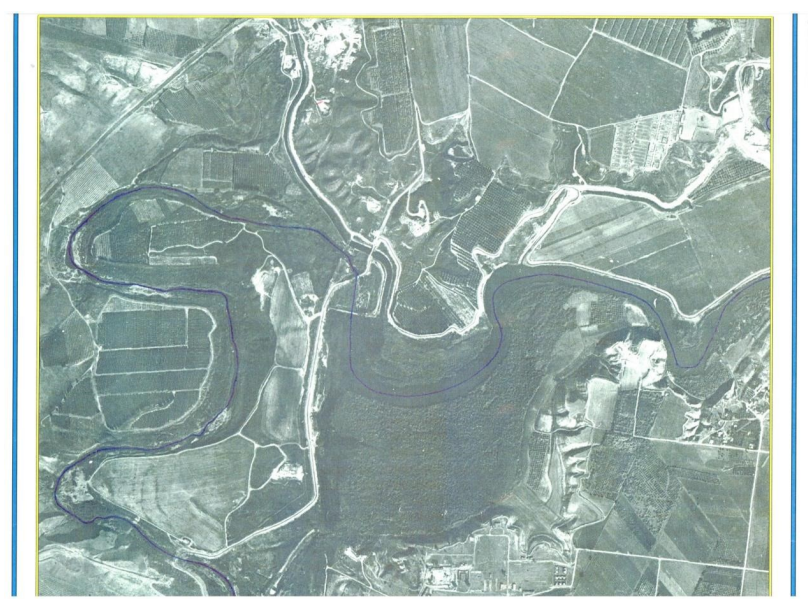

Figure 4: The international boundary in Naharayim on the orthophoto of the 1994 peace treaty

The peace treaty says that as required or once every five years the boundary line will be adapted in the case of natural and gradual changes (accretion) in the course of the river. As presented here, since 1994 only slight changes in the course of the Jordan River have occurred, most of them less than 10 meters, in comparison with changes of hundreds of meters in the past. This is a result of the drastic reduction of the water flow in the rivers due to excessive use of the water resources of both rivers to support the growing requirements of the population on both sides. The population on both sides of the rivers has expanded more than ten times since the time of the British Mandate. The issue of maintaining the river boundary has been discussed by the JTE, by discussing ideas like preparing an orthophoto every five years for monitoring the river course lines, and other ideas.

In addition to geographic changes there were changes of the political status and the legal status over the years. We will describe the changes with reference to a sub-division of the river boundaries regarding three sections: the Yarmouk River from Hamat-Gader/Al-Hama to the confluence of the river with the Jordan River (in Naharayim); the Jordan River from Naharayim to Khor Buleibil (near Tirat Tsvi); and the Jordan River from Khor Buleibil to the Dead Sea. During the British period all three sections were considered part of the international boundary between Palestine and Trans-Jordan. Later on, in the Yarmouk section, the ADL followed the Yarmouk except for a sub-section in the Naharayim basin where the 
ADL followed a line east of the rivers. It is worth noting that during the years 1950-1967 the Syrian Army dominated the northern bank of the Yarmouk between Hamat-Gader/Al-Hama and Tel Dover, violating the GAA. During the years 1967-1994 the line in this section changed status, becoming a cease-fire line, but since the 1994 peace treaty, it has returned to be an international boundary. The line along the Jordan River, from its confluence with the Yarmouk at Naharayim down to Khor Buleibil, was considered as an ADL in the years 1949-

1967 and a cease-fire line in the years 1967-1994. Since 1994 it has been part of the Israel- Jordan international boundary. The line along the southern section of the Jordan River between Khor Buleibil and the Dead Sea was a domestic Jordanian administrative line during the years 1949-1967, a cease-fire line during the years 19671994, and since 1994, according to the Israel-Jordan Peace Treaty it defines a line between the Hashemite Kingdom of Jordan and an area that came under Israeli military control in 1967 (the West Bank). There is an additional $17 \mathrm{~km}$ line along the Yarmouk north-east of Hamat-Gader/Al-Hama between the Kingdom of Jordan and the Golan Heights, which has been under Israeli rule since 1967 and under Israeli law since December 1981. The boundary line in this sub-section had been considered a cease-fire line during the years 1967-1994, and since 1981 Israel has considered this line the boundary of the Golan Heights, whereas Jordan has considered it as part of the historic Jordan-Syria international boundary, which had been initially agreed at the 1920 Paris Convention, agreed in 1922, and finalized between Great Britain and France on October 31, 1931 (US, 1969).

\section{Land settlement boundaries along the rivers}

Most of the block plans along the lower Jordan and the Yarmouk rivers, north of Khor Buleibil, have been land settled during the 1930s. The eastern boundaries of the block plans were adapted to the center of the river courses. This process was based on large-scale field surveys. 1:2500 field sheets show in detail the two banks of the rivers, indicating the international mandatory boundary in the center of the river courses. The boundaries of the block plans did not change during the armistice period (1949-1967) in spite of the actual changes in the courses of the two rivers, up to $500 \mathrm{~m}$ from the original mandatory water course, and in spite of the fact that the topographical maps showed the changes in the courses of the rivers and changed the delineation of the ADL accordingly. Thus, during that period, in certain cases the boundaries of the block plans were located hundreds of meters to the east of the ADL after the latter moved westward, whereas in other cases the ADL moved eastwards, following movement of the course of the river, leaving large unsettled areas west of the river. A similar phenomenon occurred during the years 1967-1994 when the cease-fire lines were shown on topographical maps in locations following changes in the meanders of the rivers up to hundreds of meters westwards or eastwards, whereas the boundaries of the block plans remained in their original position (of the 1930s land settlement).

The 1994 Israel-Jordan Peace Treaty defined the international boundary in the actual centers of the rivers, leaving deviations of hundreds of meters between its location and the location of the boundaries of the land settlement. Owing to the unstable character of river courses and the practical attitude of avoiding crossing river boundaries, there was no attempt to stabilize the international boundaries by enforcing the 1930s land settlement boundaries on the changing water courses of the rivers. The security reality contributed to this trend, since security roads and security fences were constructed along the upper level of the river valleys, preventing free civilian access to the rivers, thus reducing local utilization of river waters.

Following the drying of the lower Jordan and the lower Yarmouk as a result of large water utilization projects, our analysis shows that during the years 1994-2014 the course of the lower Jordan River was very stable, showing only slight changes of about 10 meters. The stabilization of the lower Jordan, augmented by additional supportive justifications, stimulated an initiative to fix the international boundary line in the two rivers and to adapt the land settlement boundaries to the fixed international boundary in the rivers. The supporting justifications, among others, are as follows: the successful joint fixing of the coordinates of the international boundary in the Yarmouk River east of Naharayim/Baqura in 2000, due to man-made changes along the river; the successful adaptation of the land settlement boundaries in the Negev (southern Israel) and the Dead Sea area to the international boundary; manmade changes along the courses of both rivers, which annul the natural behavior of the two rivers, turning their flow to be influenced and regulated by man-made activities.

The easiest task regarding this issue is adapting the block plans along the Yarmouk to the international boundary in the Yarmouk River east of Naharayim, since the boundary in this section has already been jointly fixed in coordinates by the JTE in 2000 as a result of constructing a dam on the Yarmouk near Adassiya. This adaptation of the land settlement block plans in this section is in process at the Survey of Israel and the Land Registry.

However, the situation in the other sections, where the international boundary has not yet been fixed is different. The lowest part of the Yarmouk, only 3-4 km long, before its confluence with the Jordan River, actually represents a fully man-made environment, regulated by the Adassiya and Naharayim dams. The human intervention in this area began in the late 1920s, when a hydro-electrical power station - the Naharayim Power Station - was constructed. The works included (1) constructing a dam on the Yarmouk River; (2) digging a large water basin on the Yarmouk water course before the dam for constructing a water reservoir as part of the power station complex, connected by a canal to the Jordan River in order to augment the insufficient flow of 
the Yarmouk water during the dry season; and (3) constructing the main building of the power station with the supporting canals. The original water course of the Yarmouk before the constructions had been surveyed and is shown on a large-scale map of the power station, as well as on the 1939 original British Mandate block plan which showed the old water course bisected by the international boundary line, which was followed by the boundary of the cadastral block (Figure 5). Topographical maps of the area showed the location of the old course of the Yarmouk River inside the Naharayim Basin (Figure 6). The 1949 ADL was delimited on topographic maps differently, following the situation of forces before the GAA, cutting the basin along a diagonal straight line, not fitting the international mandatory boundary and the cadastral boundary (Figure 3). The 1967 cease- fire line followed the ADL. The 1994 international boundary was delimited according to the actual location of the river, which had been created after 1949, after the power station was abandoned and the water in the Naharayim Basin had dried up (Figure 4). A dedicated annex was assigned to a special area in part of the area between the international boundary and the old ADL line. According to the agreement the Naharayim special area is under Jordanian sovereignty and under Israeli private long-term use. After the peace agreement Jordanian farmers cleared the dense bushy flora inside the Naharayim basin, south of the actual river course, stabilizing the southern bank of the river, and they cultivate the lands up to the river, so that the only possible movement of the river is toward the Israeli side (Figure 8).

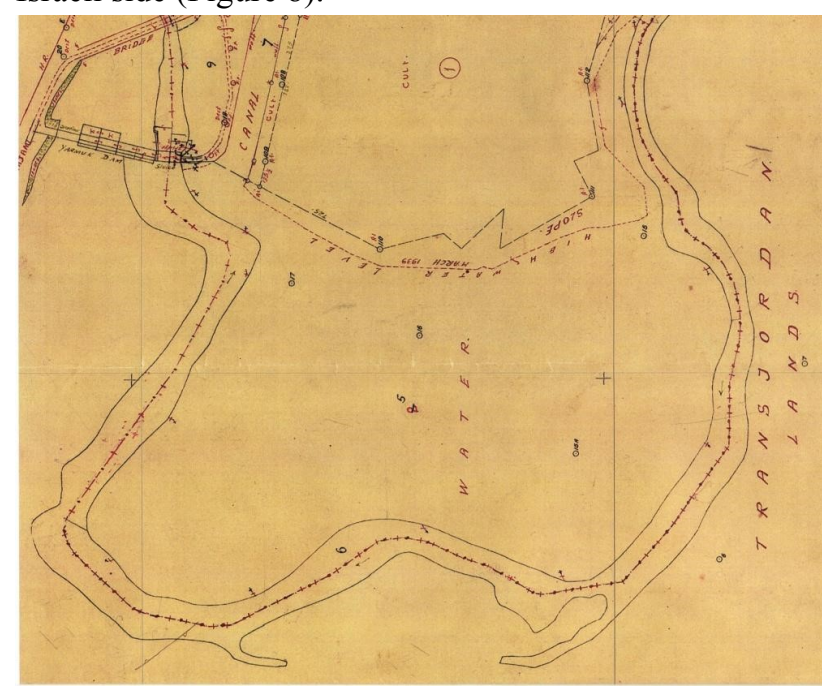

Figure 5: The international mandatory boundary in the Yarmouk River on a 1939 cadastral field sheet

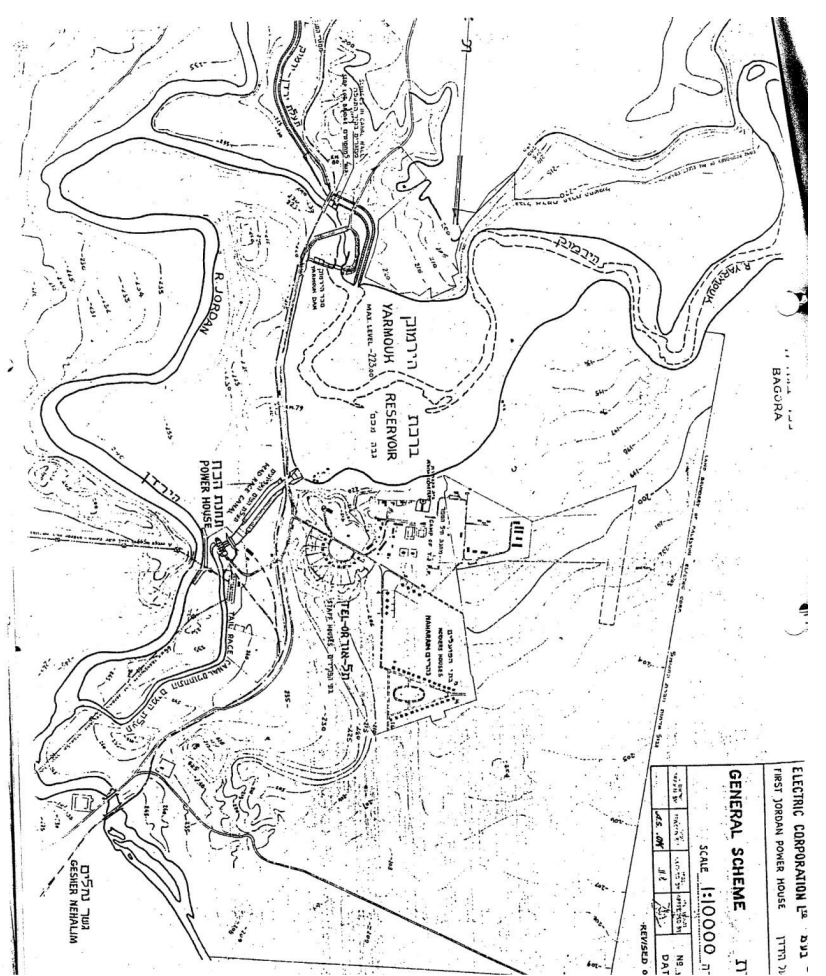

Figure 6: The course of the Yarmouk River in the Naharayim basin on an engineering map of the power station

Analyzing the situation in the area regarding the delimitation of the international boundary, one can see that it is clear that since the construction of the Naharayim dam in 1927, many substantive man-made changes have influenced the water flow of the Yarmouk in the Naharayim area, stopping its natural behavior, and forcing it to be a completely man- controlled water course. Thus, regarding the accretion principle, and following the wording of the 1994 peace agreement concerning man-made changes in the course of the river, the only option in this area is to fix the international boundary line and to adapt the land settlement to it. The only question is where should be the reference for fixing the boundary line. One option is to fix the boundary in the center of the water course of the Yarmouk River before the construction of the dam in 1927 and before the digging of the Naharayim Basin, since these changes have changed the natural behavior of the river in the area. This line also coincides with the land settlement boundary in the area, which has not been changed since the original land settlement in the 1930s until today. Such a determination complies with the international principle that does not accept river boundary changes caused by man-made interventions in the natural course of a river. The weakness of the implementation of this option today is that the construction of the Naharayim dam and the Naharayim Basin was before the Israel-Jordan Peace treaty. This may raise a legal question: did the peace treaty initialize a new situation, overruling earlier manmade changes in the course of the river? The second option arises as a fallback, in case that legally the peace treaty had initialized the reference boundary line. In such a case the alternative option is to fix the boundary line in 
the Yarmouk River in Naharayim according to the delimitation of the boundary line in the 1994 IsraelJordan Peace Treaty. This refers to the remaining $3 \mathrm{~km}$ section in the Yarmouk River, from the international boundary in the Yarmouk which had already been fixed due to the construction of the dam on the Yarmouk near Adassiya in 2000 (Figure 7), until the confluence of the Yarmouk with the Jordan River.

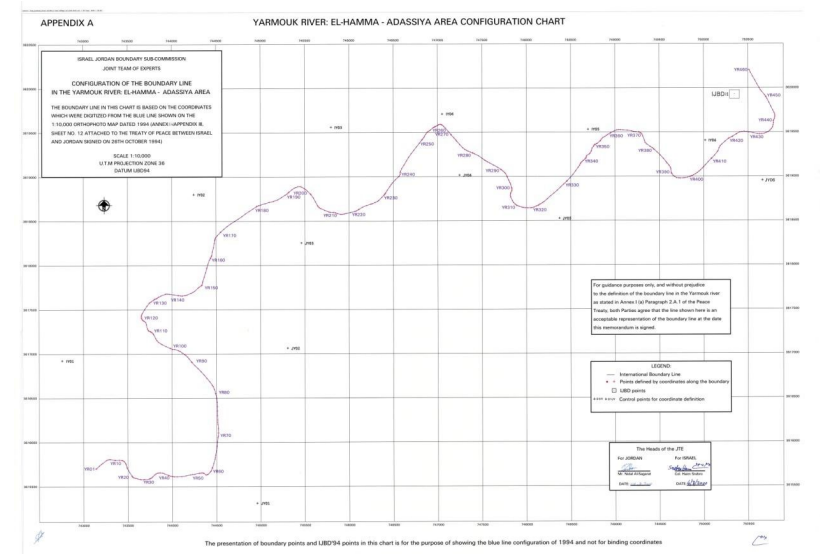

Figure 7: The fixed international boundary in the Yarmouk River (in 2000) east of Naharayim

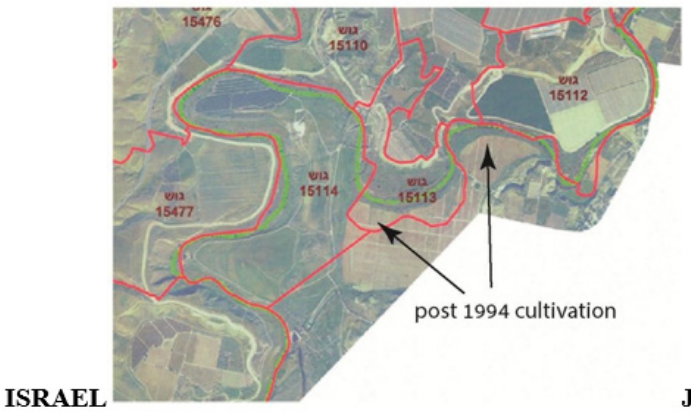

JORDAN

Figure 8: The Naharayim area in 2014 on a color orthophoto The new (post 1994) cultivated areas cover the Naharayim basin south of the 1994 boundary. (The green dotted line shows the 1994 international boundary. The red lines show the original cadastral boundaries)

A theoretical third option is to leave the boundary line in this area unfixed, depending on natural and gradual changes (accretion); however, this option of the peace agreement does not have any significance in this area anymore and is actually void, after being overruled by the instruction of the peace agreement that: "Artificial changes in the course of the rivers shall not affect the location of the boundary unless otherwise agreed." (Israel-Jordan Peace Treaty, Annex I(a), chapter 2.A.). Several reasons lead to this conclusion: (a) the water flow in this short boundary section is completely influenced and regulated by two dams on the river - the Naharayim and the Adassiya dams - and there is no regular and natural flow of the Yarmouk River in this area; (b) all of the Yarmouk water is used before the Adassiya Dam, so that the natural Yarmouk is actually dry in this section, west of the dam. Today, the actual shallow flow in the Yarmouk river bed in this section consists of sewage and drainage of the lands of two villages (Massada and Sha'ar
Ha'Golan); (c) the Jordanian lands on the south side of the river course have been prepared and cultivated after the 1994 peace treaty, by uprooting the dense flora and artificially stabilizing the south bank to avoid the sweeping away of the cultivated soils. These are artificial changes that should not change the course of the boundary according to the Israel-Jordan Peace Treaty (and according to international customary law).

From this analysis one can learn that the boundary line in this short section of the Yarmouk River can be fixed by coordinates following one of two options: either following the center of the course after the September 1, 1922 boundary definition and before the 1927 construction of the Naharayim Dam and the Naharayim Basin or following the delimitation of the international boundary in the 1994 peace treaty. Following such fixation of the international boundary, the domestic boundaries of the land settlement block plans should be adapted to the fixed international boundary.

\section{The influence of changes in the Jordan River course on the international boundary}

The international mandatory boundary between Palestine and Trans-Jordan was determined in an Order of the British High Commissioner on September 1, 1922, in the center of the Jordan River, from its confluence with the Yarmouk River until its estuary to the Dead Sea. Detailed surveying of the upper part was done several years afterwards for constructing the electrical power station in Naharayim. During the 1920 s and the 1930 s cadastral field surveys were conducted along the upper part of the Jordan Valley, from the Sea of Galilee to the area of Bet Shean, to support land settlement in the area (in the scale of 1:2,500). The beginning of the surveys, close to the time that the international mandatory boundary was determined, can serve for defining the initial reference line of the Jordan River at the beginning of the British Mandate. Great Britain governed both sides of the river. Both banks of the river were shown on the field survey sheets and the international boundary was marked in the center of the course of the river. The Jordan River south of the Bet Shean Valley until the Dead Sea was mapped during the early 1940s on a 1:20,000-1:25,000 scale. These maps show the Jordan River and the international boundary along its course. German and Australian WWI aerial photographs cover limited parts of the river but they are not vertical, are of poor quality and are inadequate for comprehensive analysis. British military aerial photographs at the end of WWII are useful for partial monitoring of the river's course.

In spite of the fact the determination of the 1922 international boundary referred to geographical natural features (like the Dead Sea and the Jordan and Yarmouk rivers), the determination did not refer to possible changes in these features over time. Such an issue was raised in 1927, following a significant change in the course of the Jordan River, due to a flood transferring a large strip of land (about $800 \mathrm{~m}$ ) from the west side of the river (Palestine) to the east side (Trans-Jordan). The question whether the change in the river leads to a change 
in the boundary line was raised by the Chief Secretary of the Government of Palestine in a letter to the Principal Secretary for the Colonies in London. He wrote that he knows that due to the sudden change in the course of the river, according to international law the boundary should remain in the old abandoned water course, but clarified that the Government of Trans- Jordan preferred to follow the actual new water course, and indicated the practical advantage of such an approach. Clarifying the preference of following the river because of difficulty of reestablishing the former course of the river, he asked if there are precedents in other places of the world "for retaining an international boundary in the center or 'thalweg' of a river that have shifted its course" in order to justify such a decision by the Government of Palestine.

The Foreign Office clarified its policy that where there are no special circumstances, the rules of accretion and avulsion should prevail ${ }^{8}$. The Army Council considered that "there should be a little difficulty in re-establishing the position occupied by the course of the river at the time of demarcation" (in 1922). In his response to the Government of Palestine, the Secretary of State for the Colonies cited the guiding principles and considerations. In addition, as requested, he also referred to "a few cases where a river had been diverted from its original channel and the boundary also has been changed in such a manner as to make it follow the new course". On September 12, 1927 the High Commissioner (HC) for Palestine and Trans- Jordan informed the Secretary of State for the Colonies that "with the concurrence of the Trans-Jordan Government, I have decided to adopt the 'thalweg' of the River Jordan as the Boundary between the two territories. 2. This decision will involve periodical minor changes in the boundary, as the 'thalweg' of the river shifts, but will probably prove to be the most practical solution to the question."

One should consider that both the Secretary and the HC tried to minimize the description of the Jordan River changes in their letters, in order to justify their view of choosing an easy practical decision rather than following the international law. The first one referred to "the narrow gorge through which the river flows". The latter referred to "minor changes in the boundary". In fact, the width of the lower level of the Jordan Valley through which the river flows (Geon Ha'Yarden - the Zor) ranges up to 1.2 $\mathrm{km}$, and the changes in the course of the river deviate up to 500 meters.

\footnotetext{
${ }^{8}$ Prescott and Triggs (2008)

indicate that territorial changes that are results of a flood or the formation of new islands are considered as avulsion.
}

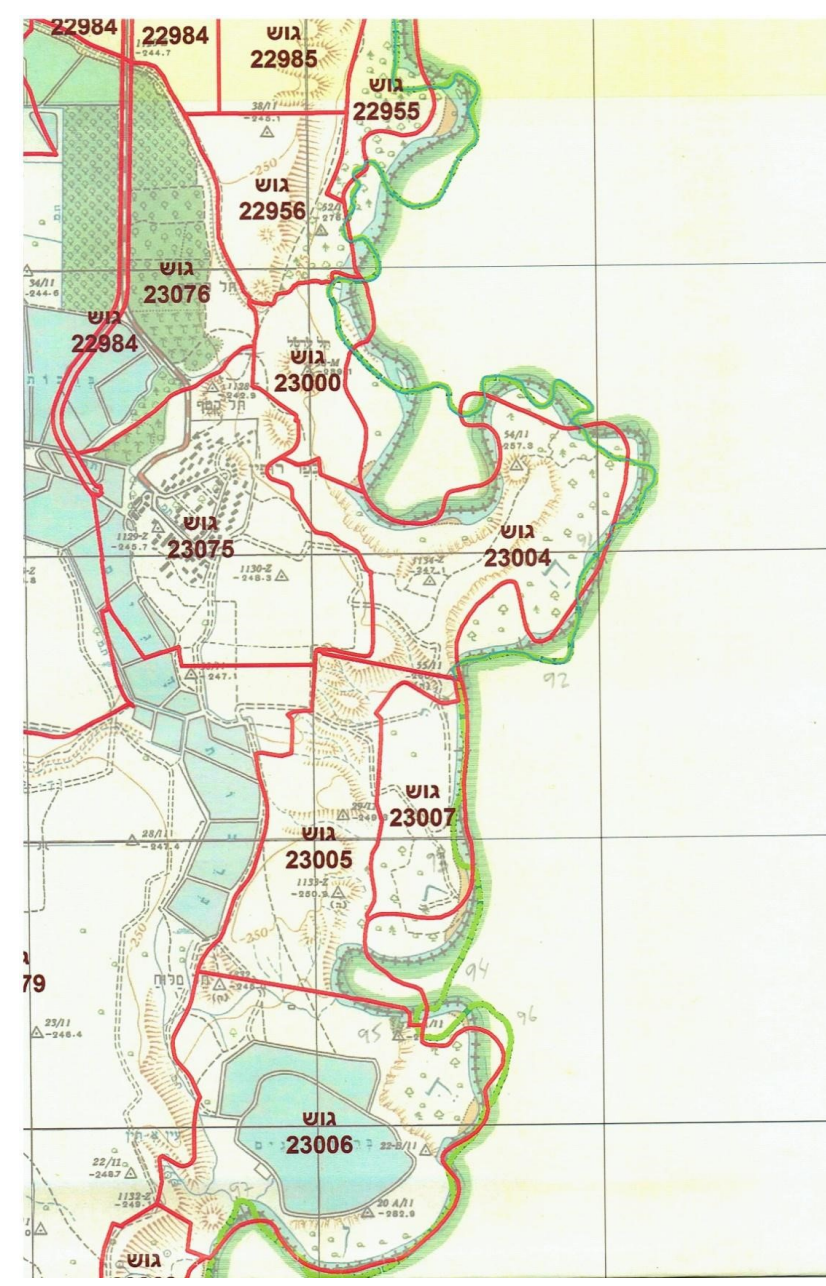

Figure 9: Boundary changes following changes in the Jordan River (in red - 1930, land settlement boundaries; +++ on the background map - the ADL in 1962; in green - the 1994 international boundary)

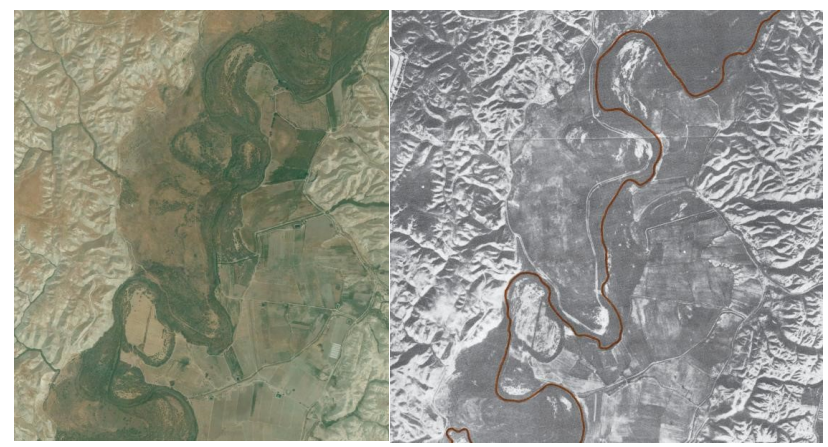

Figure 10: Changes in the Jordan River's water course and abandoned river beds in 1994 (right) and 2010 (left) on aerial photographs

The water course of the lower Jordan continued to change up to deviations of $500 \mathrm{~m}$ during the next decades. Figure 9 shows the courses of the upper section of the river in the 1930s, the 1960s and the 1990s. The significant differences between the river courses are seen clearly.

The aerial photo in figure 10 provides a visual presentation of old abandoned river courses. Part of the changes was gradual, but most of them resulted from 
strong sudden floods during very rainy seasons, like in 1927. The continuous process of drying of the water sources of the Lower Jordan decreased the changes in the water course of the river from hundreds of meters in the past to several meters. Figure 11, which shows the water courses in 1994 - the time of the peace treaty - and in 2014, reflects the stabilization of the water course. Most of the differences between these years are less than $10 \mathrm{~m}$, with a few exceptions of 10-15 m, which may be related to human interpretation of the center of the river. Furthermore, in addition to the contribution of the dense flora, which has developed due to the slow flow, to the stabilization of the river course, also man-made activities have contributed to stabilizing the water course. These include construction of barriers and fences to protect cultivated lands adjacent to the river course. The fences on the Jordanian side, which are based on rigid stones, are more influential.

The man-made changes are sufficient for the two sides to agree on fixing the boundary line according to the 1994 peace treaty line. The minor changes in the water course since 1994 support such a recommendation. In addition, no change is anticipated in the water sources of the river, since the water has to support the water requirement of the growing population on both sides, which has already multiplied by more than ten times since the time of the British Mandate, and continues to grow rapidly. On this basis, we recommend that both sides fix the boundary line in the river, along the jointly agreed international boundary, delineated in the 1994 Peace Treaty. This should be done jointly, similarly to the fixation of the boundary line in the Yarmouk in 2000. After the international boundary is fixed, the cadastral boundaries should be adapted to the fixed international boundary. Until both sides agree on fixing the international boundary, we recommend (1) defining a line along the maximum range of changes in the water course of the lower Jordan, (which is about $10 \mathrm{~m}$ on each side), and (2) stabilizing the cadastral boundaries by adapting these boundaries to the limit line of the range of changes, creating a narrow borderline cadastral block - several meters wide - as a buffer block, which will be considered a boundary block, the external boundary of which is defined in the center of the river course, being subject to slight changes in the water course.
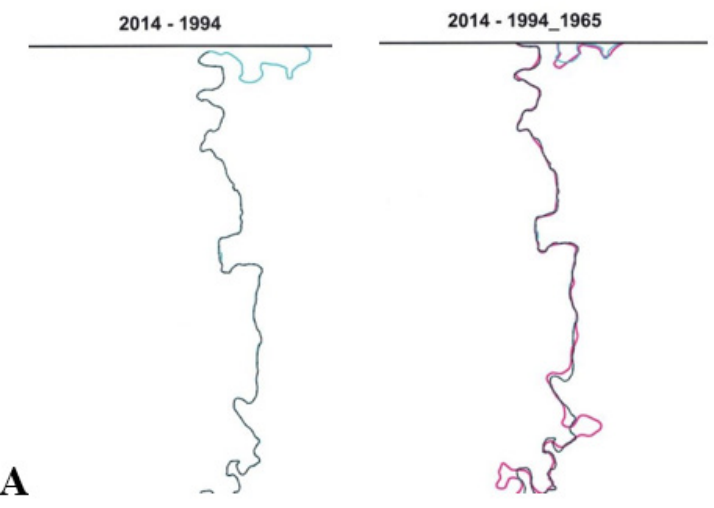

B
Figure 11: The stabilized Jordan River's water course 19942014 (A). (The line in red on the right side shows the river's course in 1965 (B))

\section{Conclusion and recommendations}

There is no obligatory international convention regarding river boundaries similar to the UN Convention on the Law of the Sea. As a result, states rely on decisions of ICJ and international tribunals, on customary practice of agreements between countries, and on studies of scholars. The doctrine that a boundary line in a changing river follows the changes in the case of accretion, when the changes are natural, gradual and not perceivable when they are formed and does not follow the changes when they are sudden or when they are a result of manmade activities - has not been accepted as an obligatory principle in international law.

This doctrine has been adopted in many cases and fulfils many criteria that check the qualification of principles to be considered as international law. Such cases include the 1911 decision of the tribunal of arbitrators in the Chamizal case, many bi-lateral agreements, including the Israel-Jordan Peace Treaty, and many law books and scholarly works. However, ICJ did not decide on it unequivocally, and there are countries that do not adopt these principles in their agreements in order to avoid local complications.

A change in a course of a boundary line transfers land from one country to another. This is harmful to the population of the losing side, to the stability of the boundary and to the relations between the two countries. On the other hand, breaking off the connection between the course of the river and the course of the boundary prevents the accessibility of the residents of one of the countries to the river, thus affecting their use of this essential resource. Even if it is concluded that for the sake of stability and legal clarity it is recommended that countries should avoid delimitation of boundary lines in rivers, and with reference to geographic landscape features that are not precise and unequivocal, one cannot ignore the fact that river boundaries make up one third of the international boundaries throughout the world.

A relevant global phenomenon that influences the situation of rivers is the dramatic population growth during the last century, which has sharply increased the use of rivers and their pollution. Other influential global developments include climate changes that damage water sources, increasing irregularity of river flows, especially in areas that are on desert edges, characterized by seasonal floods. Lack of water caused many countries, sometimes under the framework of multinational projects, to regulate the flow of water in rivers, to stabilize it by constructing dams and artificial water reservoirs, to stabilize the river banks or to canalize the river bed. Projects of water collection and water use, including pumping out water before it gets to the river, or sometimes along the course of the river, contribute to the drying out of rivers, and are considered artificial human intervention in the natural flow of rivers, so that most of the boundary rivers cannot be considered as preserving 
their natural behavior. These artificial changes, rule out the rationale of referring to the natural behavior of the river that stood as the basis of the principle of accretion. If the transfer of soil by the river is influenced by manmade activities, it is not right to grant a country the right to unilaterally influence the flow and course of the river, and as a result to change the boundary line in favor of that country, adding lands to the country's territory on the account of another country.

In light of this situation, it is often right to fix the boundary line in the river between two countries, according to the course of the river on an agreed reference date, and to deal with separate accomplishing agreements regulating other issues connected to the river. Such issues may include accessibility and rights of use of the river waters by the two countries, covering the issue of possible local changes in the river course in reference with the boundary line.

The Israel-Jordan Peace Treaty states that the boundary line in the Jordan and Yarmouk rivers will follow natural changes (accretion or erosion) in the course of the river unless otherwise agreed. Here we have reviewed the courses of the two rivers during the last century, focusing on the changes in the river courses as a result of natural and artificial intervention, including constructing dams and diverting water by canals and pipes under the framework of national water projects. We have shown how these projects have influenced the drying up of the two rivers during the last decades. In addition to blocking the natural water flow of the two rivers, the banks of the courses in which the rest of the water, which is mainly based on sewage and local drainage, are stabilized by farmers who cultivate the adjacent lands and construct fences along the river banks in order to prevent the cultivated lands from flooding.

In principle, the artificial works have created a situation that has turned the relevant peace treaty paragraphs, dealing with changes in the river course (accretion or erosion) into inapplicable conditions. Under the existing circumstances only the peace treaty option of setting the boundary line according to artificial changes is applicable. As a result it is recommended to fix the boundary line in the two rivers by coordinates according to a mutually agreed upon reference line. The existing reference line is the boundary line delineated in Annex I to the October 26, 1994 Peace Treaty. Both sides have already agreed to fix the boundary line along its main section in the Yarmouk River between Hamat- Gader/AlHama and Ashdot-Yaakov/Adassiya in 2000, following the construction of a dam on the Yarmouk at Adassiya. The JTE of the JBC set coordinates to the line in this section according to the delineation of the boundary line on the orthophoto of the 1994 Peace Treaty. The JBC formally approved these coordinates and considered them to be part of the annex to the peace treaty. A similar procedure is recommended for the rest of the boundary line in the Jordan and Yarmouk rivers.

From a practical point of view, the changes in the course of the Jordan River decreased from hundreds of meters, when the river behaved as a natural river, to ten meters with several exceptions of up to 15-20 m since the 1994 Peace Treaty. This decrease has occurred gradually since the 1960s, following the construction of large water supply projects on both sides. The consequence of that is that fixing the boundary line will have almost no influence on the reference between the boundary line and the river course.

On this basis it is recommended to fix the boundary line in coordinates according to the delineation of the line in the 1994 Peace treaty in a joint Israeli-Jordanian process, following the process of fixing the boundary line in the Yarmouk in 20009. This will enable fixing the cadastral boundaries along these rivers, by adapting the land settlement boundaries to the agreed and fixed international boundary. Until such mutual agreement on fixing the international boundary line occurs, it is recommended to delimit a line indicating the rage of changes in the Jordan water course (about $10 \mathrm{~m}$ ) in order to adapt the cadastral blocks to this line, and to leave a border strip, several meters wide, to be defined as a flexible border block, limited by the center of the course of the river, depending on the changes in the course of the river as agreed upon by both sides.

\section{*Note}

The views expressed in this article are the author's and do not necessarily reflect the views of the Government of Israel including the Survey of Israel, or the view of the Israel-Jordan Joint Boundary Commission.

\section{Acknowledgements}

The author thanks to the Survey of Israel and its employees, including DG Ronen Regev, Eti Benin, Hana Landman, Lea Ezra and Lena Rubinshtein for their support with the maps and illustrations.

\section{References}

Almog R., (2012) Geomorphological Review and Hydrological Systems, in: The Jordan River and its Surroundings - from Naharayim to Nahal Bezek, an ecological survey, editors: Gal A. and Perlberg A., Deshe Institute. Final report prepared for the Southern Jordan Drainage Authority, pp 25-42 (in Hebrew).

Angell J.K., (1854) A treatise on the law of watercourses, Fifth edition. Boston: Little, Brown and Co.

Biger G., (1988) 'Physical Geography and the Law: The Case of International River Boundaries', GeoJournal 17 (3), 341-7.

Biger G., (1994) River and Lake Boundaries in Israel, in: The Middle East and North Africa, World Boundaries volume 2, edited by Clive Schofield, Richard Schofield, IBRU 1994, Routeledge London.

Boggs S.W., (1937) Problems of Water Boundary Definition: Median Lines and International Boundaries through Territorial Waters, Geographical Review 27, $445-456$ 
Boggs S.W., (1940) International Boundaries: A Study of Boundary Functions and Problems, Columbia University Press, New York.

Bouchez L. J., (1963) The Fixing of Boundaries in International Boundary Rivers,

International and Comparative Law Quarterly, Volume 12, 1963, 3: 789-817.

Bracton H. de, (1883) Legibus et Consuetudinibus Angliae. Edited by T. Twiss. London: Longman \& Co. (cited by Donaldson, 2011)

Brawer M., (1968) The Geographical Background of the Jordan Water Dispute, in: Essays in

Political Geography, edited by Charles A. Fisher, Methuen, London.

Brawer M., (1988) The Boundaries of Israel (in Hebrew), Yavne Publishing House.

Cukwurah A.D., (1967) The Settlement of Boundary Dispute in International Law, Manchester.

Department of Commerce, (1971) Sino-Mongolian Border Protocol, Translations in Communist China, no. 131, Joint Publications Research Service, Washington D.C.

Dinshtein Y., (1972) The Internal Authority of a State (in Hebrew), Shoken publishing house and Tel Aviv University, p. 37

Donaldson J., (2009) Where Rivers and Boundaries Meet: Building the International River Boundaries Database. Water Policy 2009, 11:629-644.

Donaldson J., (2011) Paradox of the Moving Boundary: Legal Heredity of River Accretion and avulsion. Water Alternatives 2011, 4:155-170.

Eritrea-Ethiopia Boundary Commission (EEBC), (2002) Decision on delimitation of the border between Eritrea and Ethiopia, Permanent Court of Arbitration, The Hague, 13 April 2002.

FIG: International Boundary Making, (2013) Editor: Haim Srebro, The International Federation of Surveyors: FIG Publication NO 59, Copenhagen, Denmark.

Graf W., (1983) Flood-Related Channel Change in an Arid Region River, Earth Surface Processes and Landforms, 8:125-139.

Grainger S, and Conway D., (2014) Climate change and IRBs: fixed points in shifting sands, Wiley Interdisciplinary Reviews: Climate Change Volume 5, Issue 6, pages 848-835, November/December 2014.

Grotius, H., (1715) Of the rights of war and peace (three volumes). London: Printed for D. Brown, T. Ward and W. Meares. Available online at: Gale, Eighteenth Century Collections Online http://find.galegroup.com/ecco/ (cited by Donaldson, 2011))

Holtzman R., Shavit A., Segal M., Vangush A., Farber E., Gabrieli I., Glazman H., (2002) Sufficiency measurements in the southern Jordan River, Water and
Irrigation, monthly no. 423, the organization of water workers, pp. 14-17 (in Hebrew).

International Boundary Commission (IBC), (1911) Award before the International Boundary Commission, enlarged by the Convention between the United States and Mexico of June 24, 1910, In the matter of the international title to the Chamizal tract - section Fixed Line Theory. American Journal of International Law 5(3): 791-805.

International Boundaries and Water Commission (IBWC), (1933) Rectification of the Rio Grande, Convention between the United States of America and Mexico, 1 February 1933. Treaty Series No. 864, www.ibwc.gov (accessed 22 October 2015).

IBRU: Centre for Borders Research, (2008) International River Boundaries Database (IRBD), Durham University, https://www.dur.ac.uk/ibru/resources/irbd/search. (accessed 22 October 2015).

International Court of Justice ICJ, (1992) Case concerning the land, island and maritime frontier dispute (El Salvador/Honduras, Nicaragua intervening) judgment of 11 September 1992. General List No. 75: 351 .

International Court of Justice ICJ, (1997) Case concerning the Gabčíkovo-Nagymaros Project (Hungary/Slovakia) Judgment of 25 September 1997. ICJ Reports 1997.

International Court of Justice ICJ, (1999) Case Concerning Kasikili/Sedudu Island (Botswana/Namibia). Judgment of 13 December 1999. General List No. 98 (13). ICJ Reports 1999.

International Court of Justice ICJ, (2003) Application for revision of the judgment of 11 September 1992 in the Case concerning the Land, Island and Maritime frontier dispute (El Salvador/Honduras, Nicaragua intervening) (El Salvador v. Nicaragua) judgment of 18 December 2003. ICJ Reports 2003.

International Court of Justice ICJ, (2005) Case Concerning the Frontier Dispute (Benin/Niger). judgment of 12 July 2005, General List No. 125. ICJ Reports 2005.

International Court of Justice ICJ, (2009) Case concerning the dispute regarding navigational and related rights (Costa Rica v. Nicaragua) judgment of 13 July 2009. General List No. 133.

International Court of Justice ICJ, (2010) Case concerning pulp mills on the river Uruguay (Argentina v. Uruguay) Judgment of 20 April 2010. General List No. 135.

International Court of Justice ICJ, (2013) Press Release "Certain Activities carried out by Nicaragua in the Border Area" (Costa Rica v. Nicaragua). General List No. 35. 2013.

International Court of Justice ICJ, (2013) Press Release "Construction of a Road in Costa Rica along the San 
Juan River" (Nicaragua v. Costa Rica). General List No. 39. 2013.

Jones S.B., (1945) Boundary Making A Handbook For Statesmen, Treaty Editors and Boundary Commissioners, Washington D.C Carnegie Endowment For International Peace.

Lauterpacht E., (1960) River Boundaries: Legal Aspects of the Shatt-Al-Arab Frontier, International and Comparative Law Quarterly, vol. 9, 1960, p. 222.

Kalvo R. and Ben Tsvi A., (2005) Spatial Analysis of the drainage basin of the lower Jordan and estimating its ground flow into the Dead Sea, Report GSI/17/2005 (in Hebrew), Geological Survey, Ministry of Infrastructure, Jerusalem.

Klein M., (1990) A River as a system in a dynamic balance, or: what happened to the bed of the lower Jordan? (in Hebrew), Mada, 2, Witszman Institute publishing house.

Klein M., (1996) The Water Balance of the Jordan River - Sources, Accuracy and Reliability of Data (in Hebrew), Horizons in Geography, 44-45, pp 83-90.

Klein M., (2000) Floods in the Zor (of the Jordan river) and their influence on land uses (in Hebrew), Horizons in Geography, 52, pp 89-101.

McCaffrey S., (2007) The Law of International Watercourses, 2nd edition, Oxford, UK: Oxford International Law Library; 2007, 41-47.

Prescott J.R.V. and Triggs G., (2008) International frontiers and boundaries: Law, politics and geography. The Hague: Martinus Nijhoff Publishers.

Riquélme A., (1849) Elementos de derecho público internacional tomo I. Madrid: Imprenta de D. Santiago Saunaque.(cited by Donaldson, 2011)

Salman S., (2000) International Rivers as Boundaries The Dispute over Kasikili/Sedudu Island and the Decision of the International Court of Justice. Water International 2000, 25:580-585.

Salman S. M. A., (2006) International Water Disputes: a new breed of claims, claimants, and settlement institutions. Water International 31(1):2-11.

Schattner I., (1962) The Lower Jordan Valley, A study in the fluviomorphology of an arid region, Scripta Hierosolymitana, publications of the Hebrew University, Jerusalem Volume XI, The Magnes Press, 1962.

Shaw M. N., (2014) International Law, Seventh edition, Cambridge University Press.

Solel A., (1991) The Geographic Delimitation of the Land Rights in Israel, Survey of Israel (in Hebrew).

Srebro, H., (2005) A Process Driven Boundary Making Model: Generalizing the Case Study of the Gulf of Aqaba and the Arava Valley. Ph.D. Thesis, Bar Ilan University.

Srebro H., (2012) The Boundaries of Israel Today, Survey of Isarel.
Srebro H., (2012) International Boundary Making Methodology and Practice: The case of the Israel-Jordan Boundary, FIG WW 2012, Rome, Italy, 6-10 May 2012.

Srebro H., (2014) International Boundaries - The IsraelJordan Boundary, private publishing (in Hebrew).

Rubinstein E., (2004) On the Boundary and on the IsraelJordan Boundary (in Hebrew), Parashat hakat, 170, Ministry of Justice, Department of Hebrew Law

The Palestine Order in Council, (1922) Official Gazette of the Government of Palestine, 1 September 1922.

Toye P., (ed.) (1989) Palestine Boundaries 1833-1947, Farnham Common: Archive Editions.

Treaty of Peace between the State of Israel and the Hashemite Kingdom of Jordan, 26 October 1994.

UK Land Registry, (2015) Land Registry Plans: Practice Guide 40, Supplement 3, updated 25 June 2015. https://www.gov.uk/government/publications/landregistry-plans-boundaries/land-registry-plansboundaries-practice-guide-40-supplement-3 (accessed on 22 October 2015)

UN, (1978) Register of International Rivers, Prepared by the Centre for Natural Resources, Energy and Transport of the Department of Economic and Social Affairs of the United Nations, Pergamon Press, Oxford.

U.S. Department of State, (1969) International Boundary Study No. 94: Jordan-Syria Boundary Study, The Geographer, December 30, 1969.

U.S. Supreme Court, (1875) County of St. Clair v. Lovingston. 90 US (23 Wall). 46.

U.S. Supreme Court, (1890) Jefferis v. East Omaha Land Company. 134 US 178-198.

U.S. Supreme Court, (1892) Nebraska v. Iowa, 143 U.S. 359-370.

U.S. Supreme Court, (1918) Arkansas v. Tennessee. 246 U.S. 158-177.

U.S. Supreme Court, (1972) Nebraska v. Iowa. 406 US 117-126.

Vattel E. de, (1787) Law of nations: or Principles of the Law of Nature: applied to the Conduct and Affairs of Nations and Sovereigns, Book I. translated from French. Dublin: Printed for Messrs. Baerry and Rogers. (cited by Donaldson, 2011)

Woolrych H.W., (1853) A treatise of the law of waters; including the law relating to rights in the sea. Philadelphia: T. \& J.W. Johnson. (cited by Donaldson, 2011) 